\title{
CHARLIE HEBDO ATTACKS IN THE LIGHT OF AQUINAS' DOCTRINE OF DOUBLE EFFECT AND IGNATIEFF'S LESSER EVIL THEORY
}

\author{
LUKÁŠ ŠVAŇA
}

\begin{abstract}
The aim of this paper is to study and analyse the Charlie Hebdo attacks from a methodological and an ethical perspective, concentrating generally, though in some cases indirectly, on the consequences of our actions and the motives behind them. The analysis examines the issues of liberties, freedoms and responsibilities in general and further applies these values to the phenomenon of terrorism in contemporary society. The primary goal of this study is to use the Thomas Aquinas doctrine of double effect and Michael Ignatieff's lesser evil theory to appraise specific acts of terrorism. The article suggests that certain freedoms should be limited in democratic societies and thus ensure safety.
\end{abstract}

Key words: doctrine of double effect; lesser evil theory; terrorism; Charlie Hebdo.

\section{Introduction}

This paper is a theoretical reflection on the terrorist attack in France targeted against the editorial staff of the French satirical magazine Charlie Hebdo. The incident occurred on 7th January 2015 and was immediately portrayed as a terrible act of terrorism and slaughter directed at civilian targets. The magazine is well known for using articles, illustrations and caricatures as a means of presenting opinions on events, individuals and facts. Its goal was to remain strongly apolitical and non-religious. We can assume that the motivation for producing rather offensive caricatures was not influenced by tension, hatred or hostility and we can expect that the aim was not to evoke such negative emotions. It is questionable as to whether this was a successful strategy and whether the editors (or any other persons involved) crossed a line they should not have. There is also the issue of how we should understand the concept of freedom of speech and the press and all the relevant responsibilities associated with that. It seems that this freedom was misunderstood and taken to mean the absolute freedom to publish whatever was authorized by the editor-in-chief and the magazine committee usually consisting of the magazine's owners. The political, religious or other cultural satire and irony used was meant to amuse and its targets were not limited to anything or anyone. Nevertheless, the members of the magazine staff became an important target for the terrorists in their attacks which killed 12 people. It was supposed to be an act 
of revenge for the mockery of their appraised Prophet Muhammad-an idol for Muslims, a mediator between Allah and the people, and a symbol of perfection and ideal founder of Islamic religion. I feel it is necessary to add that many of the magazine covers have carried caricatures of the Catholic religion, its representatives and key figures in recent years. It has also portrayed and mocked many other historical and political figures, events and social and cultural events. The idea that the illustrations had a purpose-built character must therefore be strictly rejected as it can clearly be seen that Islam was not the only target of these sophisticated attacks.

Analyzing the conflict between freedom of speech and tolerance using the lesser evil theories may be of crucial importance and may possibly serve as moral guidance in such problematic cases if used to analyse them properly, objectively and without any hesitation. The analysis also focuses on the terrorists' motives and possible reasons for committing such actions as well as on finding a way in which liberal democracies bound by moral values can respond. The lesser evil theories are based on minimizing the negative consequences, i.e. causing lesser evil, rather than maximizing the benefits and positive consequences. This is a primary and important feature when compared to utilitarian concepts and/or theories. By using theories such as these I will analyse the morality and rightness on the one hand and the immorality and wrongness of actions connected with terrorism and killing civilians and for these purposes I will use Thomas Aquinas' doctrine of double effect and Michael Ignatieff's lesser evil theory. I assume that these theories are compatible as they can both be perceived as forms of moral theories that evaluate the actions of moral subjects primarily on the basis of consequences. The leitmotif of this paper is to find ways in which political and religious satire is reflected as the expression of freedom of speech within boundaries that are often perceived as vague, ineffective and confined to provocation and offensive attacks against the values of different cultures, religions, ethnicities and races.

In general, these acts can be considered to be acts of terrorism. The main motive of the attackers was to kill in revenge and the negative consequences were felt in the deaths of 12 civilians. True terrorism represents a danger and a menace which cannot and should not be considered in terms of goodness, rightness or justice. It is a form of mass violence that has no limits, disregards the immunity of particular groups, attacks suddenly and randomly and its aim is to kill or hurt as many targets as possible, and to prompt immense concern in the media. "Through dramatic, attention-riveting acts of violence, terrorists seek to focus attention on themselves and their causes through the publicity they receive, most often from news media coverage" (Hoffman, 2006, p. 255). Whether the attack on the Charlie Hebdo staff was an act of terrorism or a kind of retaliatory, just measures provoked by derisive caricatures and articles directed at the very foundations of their religion and their representatives, will be a matter for discussion and analysis in this paper.

\section{Aquinas' doctrine of double effect}

The doctrine of double effect is a set of rules and principles that seeks to illustrate the causes of and the circumstances and conditions required to justify morally wrong behaviour. Just war theory is based on similar principles but is directly related to actions in warfare and associated activities. The doctrine itself is a possible starting point; it is not designed to be 
used in specific situations; the aim is that it should be a universal moral guidebook/manual worth following in particular situations. Aquinas applies the doctrine to situations in which causing harm and/or killing a person may seem inevitable and required to ensure the greater good. I believe that the doctrine itself is a version of the theory of right as it stipulates which actions can be performed and still be judged as right and justifiable. It also, though indirectly, specifies actions that should be avoided on the basis that they are wrong and unjustifiable.

Aquinas further reflects on the issue of killing an innocent man and searches for opportunities of doing so and of not doing so at any cost. He claims that killing a sinner is allowed based on the idea of the common good that is being destroyed by sin. But lives of just people preserve and support the common good and that is why it can never be allowed to kill an innocent man (Aquinas, 1938). According to Aquinas, it is entirely possible for an action to have two effects. Using the terminology of consequentialism, the effect is identified as a consequence, though only one of the consequences is intended. Harming or killing someone results in two consequences-preserving one's own life and killing the attacker. If the motive is to preserve one's own life, then the action is not forbidden since it is natural to protect one's own life. On the other hand, it is forbidden if it is not proportionate with the cause, i.e. a moral subject uses disproportionate violence compared to what is necessary and inevitable (Aquinas, 1938). As we see, Aquinas views the act of preserving one's life as a well-grounded and justified argument for causing harm to others in relation to the proportionality between the primary evil action and our response to it. In these terms, Aquinas does not use the notions of moral, right, immoral or wrong. Instead he refers to them as being potentially intended. Some may be foreseen and some may occur by chance or under unforeseeable circumstances. According to the previous line of argument, an action can be performed only if the intention is to produce good results and a negative result is only a necessary and indirect consequence. Four more conditions must be met if the principle of double effect is to be met:

1. The act itself must be morally good or at least indifferent.

2. The agent may not positively will the bad effect but may permit it. If he could attain the good effect without the bad effect he should do so. The bad effect is sometimes said to be indirectly voluntary.

3. The good effect must flow from the action at least as immediately (in the order of causality, though not necessarily in the order of time) as the bad effect. In other words the good effect must be produced directly by the action, not by the bad effect. Otherwise the agent would be using a bad means to a good end, which is never allowed.

4. The good effect must be sufficiently desirable to compensate for the allowing of the bad effect (Connell, 1967, p. 1021) (McIntyre, 2004, § 4).

Michael Walzer reflects on the use of the doctrine of double effect in war. He suggests reformulating the third principle, which is defendable only if two outcomes are the product of double intention thus: first, that the "good" be achieved; second, that the foreseeable evil be reduced as far as possible. So the third of the conditions listed above can be restated:

The intention of the actor is good, that is, he aims narrowly at the acceptable effect; the evil effect is not one of his ends, nor is it a means to his ends, and, aware of the evil involved, he seeks to minimize it, accepting costs to himself (Walzer, 1977, p. 155). 
Walzer integrates the possibility that the intentions do not accord with the actual consequences into the doctrine. At the same time, he makes it inevitable that negative consequences will be foreseen as much as possible and eventually avoided. It is evident that this is a consequentialist position in which having respect for the intentions of moral subjects leads him to act in a particular manner.

Moreover, Gordon Graham mentions two principal objections that have been laid against the doctrine and their counter-arguments. The first is that it is too liberal to serve a useful purpose and that the principle of double effect is easily satisfied i.e. a moral subject is not to be held responsible for all unintended but foreseeable outcomes if he presents them as such. ${ }^{1}$ Our intentions, even if good, have to be pursued in the awareness of the best way of fulfilling them and although intentions are morally important, there are means we cannot properly take to carry them out. The second objection relies on the idea that I am responsible for the consequences of my actions. Though it may be true that I cannot be blamed for the consequences of which I could know nothing, I am responsible for any bad thing I do knowingly. Any contrary principles are casuistry in the bad sense and an attempt to forge a wholly artificial distance between my actions and their outcome. On the contrary, Graham claims that knowing and intending the consequences are different things. This objection is radical in the sense that it challenges something built into the heart of the doctrine-the moral relevance of intentions (Graham, 2008, pp. 74-75). Intentionality therefore becomes the crucial difference between a morally acceptable action and a formidable crime.

The attacks on the editorial staff of Charlie Hebdo magazine were directly aimed at killing civilians and their actions were not only foreseeable (from their perspective) but also intended. There may be no relevant argument to justify such crimes against humanity, human dignity and the moral law of the people involved. The absence of good intention is enough to state that the attacks were an example of heinous immoral actions without any just cause that could possibly justify them. The well-planned act was to intentionally kill the editorial staff and send a direct message that verbal or non-verbal attacks on the Islamic religious faith and beliefs would not be tolerated. If we use the doctrine of double effect as a moral guide to evaluate these actions, they fail to abide by the principles mentioned. Killing another man when there is no intention to minimize the negative social consequences, and there are no positive consequences or none proportionate to the negative consequences, is strictly forbidden. They also fail to satisfy the idea of common good. Killing in the name of one's religion is a clear example of the violation of basic moral principles and values. ${ }^{2}$ Though, the terrorists might have argued that killing civilians was not their primary intention, once they found themselves in that situation, there was no other way out. In addition, the satirical

\footnotetext{
${ }^{1}$ Graham provides the example of a terrorist holding hostages and threatening to kill them if the government does not give into his demand for the release of comrades. When his demands are not met, he shoots a hostage, and claims that the death was a foreseen but unintended consequence. His intention is to release his comrades, and if this can be accomplished without the death of a hostage, so much the better. According to Graham, this reasoning seems to fit the doctrine of double effect (Graham, 2008, p. 74).

${ }^{2}$ For more information on the issue of terrorism, religion and ethics, see: Ethics and religiously motivated terrorism (Švaňa, 2013).
} 
caricatures did not contribute to the common good, especially the common good, in the sense of international and interreligious relations. The caricatures have certainly produced tension, hatred and contempt among coexisting social groups. I believe that this is what Graham was referring to-easily satisfying the doctrine. I consider this line of argument to be mistaken and wrong for one reason. Its plausibility is based on ignoring the costs and benefits i.e. the proportionality between the harm done and the harm intended to stop the original harm from being done. The terrorists' attack could not be, in any sense, treated as a means of choosing the lesser evil and achieving the greater good. Taking a gun and killing people is not a you "find yourself in". The motivation (intentionality) behind such actions is evil.

Without any doubt, freedom of speech is one of the crucial and most important features of a democratic society. The problem arises when this freedom is taken for granted and as the absolute freedom to express one's ideas in any situation and context. John Stuart Mill claimed that "opinions lose their untouchability, if they are being expressed in situations that might lead to incite some harmful action" (Mill, 1978, p. 53). After WWII, the majority of countries agreed to prevent actions that may incite violence or hatred on the basis of a person's race, ethnicity or faith. ${ }^{3}$ The Charlie Hebdo caricatures are an example of ill judged, uncontrolled and limitless freedom of speech and a risky action that may have future consequences that might cause moral harms or disasters. The situation in which they have been presented is not an example of stable and peaceful relations between different cultures, nations and/or religions. It would have been wiser to foresee that the expected consequences would occur sooner or later. They should have known that there are some Muslims who do not hesitate to use deadly means and to react wildly, violently and disproportionately, thereby bringing discredit to the religion they think they are defending. Nevertheless, to say that the victims are responsible for their actions is one thing, but to say that they deserved punishment by death is a different claim. Setting the boundaries in a democratic society is a delicate affair, but sometimes there is no other way than to appeal to reason and a common sense morality among people (or even nations) who may feel superior to others and untouchable by harm and wrongdoing. As far as people are willing to bear responsibility for their actions, there are no real dilemmas. But it means that they should bear only personal responsibility and that they are never allowed to bear someone else's responsibility i.e. the attackers of the editorial staff must be solely responsible for their actions, but they cannot be the executors of someone else's responsibility.

The principle of double effect posits that an action (provided it is morally good or neutral) that causes serious harm may be permissible if the side effect is to promote a good end. It would not be permissible to cause the same harm as a means to a good end —only as a side (double) effect. Intentionality becomes the crucial criterion. One may foresee the possibility of harm but not intend it. What was the intention behind the Charlie Hebdo editors' decision to publish a cartoon of the Prophet Mohammed? What possible harm did they foresee but not intend? Boosting the sales of the magazine might be a good intention, but to engage in pure religious provocation for such a purpose is morally unacceptable as it fails to follow the general ideas of tolerance, human dignity and respect for dissimilar beliefs

\footnotetext{
${ }^{3}$ For example, the Constitution of the Slovak Republic guarantees the right to freedom of speech and to information and prohibits censorship. But this freedom can be restricted in order to ensure the rights and freedoms of others or the security of the state (Ústava SR , 1992, čl. 26).
} 
and values. Moreover, it fails to satisfy the Aquinas condition of it being the side effect of our actions given the previous strong criticism and opposition towards these offensive expressions of religion and belief. ${ }^{4}$

\section{Ignatieff's lesser evil theory}

Michael Ignatieff is an advocate of the lesser evil theory and he seeks to apply it to the phenomenon of terrorism and especially to the potential reactions of a democratic society built upon certain moral values and principles. Terrorism is therefore a substantial challenge for modern democracies. Ignatieff states that

a lesser evil morality is designed for sceptics, for people, who accept that leaders will have to take decisive action on the basis of less than accurate information, who think that some sacrifice of liberty in times of danger may be necessary (Ignatieff, 2004, p. 9).

The contribution this ethical perspective makes lies in its flexibility, adaptability and situational conditionality. It also warns against a general preference for one value or principle over others. It does not prioritize individual rights and freedoms, human dignity or public safety. The lesser evil theory is based on the idea that certain trade-offs can be made between values and principles when necessary. The trade-off between individual rights and security is of crucial importance. In a terrorist emergency, it is necessary to favour public safety and possibly suspend some rights and liberties. Ignatieff argues that the liberty of the majority relates directly to their safety and if people live in fear, then they are not free. The security of the majority becomes imperative (Ignatieff, 2004, p.7).

Ronald Dworkin remarks that in times of terrorist threat the compromise is not between our liberty and our security, but between our security and their liberty, by which he means the freedoms of all suspect groups and particularly the subset in violation of immigration regulations (Dworkin, 2002, p. 276). I think that our liberty should also be limited and, in times of danger, possibly restricted so we can avoid the negative consequences (greater evil) that arise when various liberties are unchecked and limitless. In his On Liberty Mill claimed that "if someone violates certain rules and bad consequences of his actions are struck upon other members of the society as well, the society must protect its members and use reprisals" (Mill, 1978, p. 74). The limitation itself is a negative social consequence but is easily counterbalanced by the potentially severe negative social consequences that it is trying to avoid. These restrictions on basic democratic liberties are commonly accepted as trade-offs of liberty to protect us from harm or loss of people's lives and other amenities. I agree that security can be of greater importance than the liberties and rights of people as people's existence is directly affected by the level of security in a country. These liberties can and should be limited and this can be done to minimize terrorist threats and civilian victims as the direct consequence. We need to realize that this is a temporary measure of last resort

\footnotetext{
${ }^{4}$ In 2006, Charlie Hebdo magazine published cartoons from a Danish magazine and the response of the strong Muslim community in France meant it was immediately faced with the complaint that it had incited racial and religious intolerance. The courts issued an acquittal on the basis of protecting freedom of speech.
} 
and prevent it from becoming the extremely dangerous standpoint that democracy should be protected at all costs, no matter the nature of the rights and liberties being violated. Although, some authors claim that there is an exception when extreme conditions require and morally justify the killing of civilians to secure the safety of the political community (the citizens of a particular country). One such author is Michael Walzer and his notion of supreme emergency is that such a condition holds when a community faces the imminent, cruel and severe threat of extermination, annihilation or enslavement. It is inevitable that we must deviate from the principle of the just war theory that civilians are not legitimate targets (the principle of discrimination) if it is to save the community from such a fate (Walzer, 2006, p. 254). ${ }^{5}$ John Rawls presented a similar potential solution for a community to survive, but he narrows the community down to a liberal constitutional republic (or at least a decent non-liberal bodypolitic) fighting in self-defense (Rawls, 1999, pp. 104-105).

It is evident that this was not the case in the Charlie Hebdo attacks. There were no imminent or severe threats that could possibly have caused the annihilation or enslavement of the entire political community. Therefore, there was no reason to attack civilian targets and we can define the actions as true terrorism. When we come back to the idea of lesser evil, one particular question may arise: Would it be legitimate and justifiable for a French government to supervise the publishing of Charlie Hebdo magazine (and possibly some others) and thereby limit one of the liberties of its citizens through censorship? Surely, it would have been reasonable to predict that without such offensive mockery and satire there would have been no attacks. No one would have been hurt or killed and twelve people would have been saved, and the prevailing ideas of intolerance would not have been so widespread, etc. The greater evil that we are trying to avoid would not have been committed. The actions of government might be viewed as the lesser evil—no one would have been killed, the mood against immigrants would be less aggressive and offensive-based on the preference of security over a particular democratic liberty. If we are to avoid severe moral harm and disaster, using the theory of lesser evil seems to be an inevitable but reasonably limited step. The concept and its use must remain open to supervision as the lesser evil may easily become a greater evil if unchecked and it must be provided with specific rules for use under specific circumstances.

The situation before the attacks was not one of imminent threat; though, to call this world a safe place would not have been appropriate. The unpredictability and randomness of terrorism means it is possible for an attack to occur anywhere and at any time. Ignatieff's lesser evil theory focuses more on these imminent threats. Fear, panic and people being worried about their lives are the true victories of terrorism and its practices seek destruction and destabilization. If there is no imminent threat to our safety, there is no need to make a trade-off between public safety and civilian liberties. The problem is that we are not always able to recognize and assess the threat of the situation and the possible outcomes of our actions. And if we are not capable of doing that, I would say, it would be best to have someone who can do it on our behalf. Someone should have told the Charlie Hebdo staff

\footnotetext{
${ }^{5}$ Walzer's idea of supreme emergency has come in for strong criticism by some authors. Joe Cole accuses the theory of not respecting human casualties and he synthesizes his reservations into 11 points among them: internal consistency, the point of view problem, the human sacrifice problem and ungrounded protection of the political community (Cole, 2013, pp. 14-17).
} 
that their actions were not entirely appropriate and that their illustrations were becoming very offensive, vulgar and inappropriate and that someone might possibly interpret them in the worst possible way. Responsibility is useless if not practiced by a moral subject.

Eve Garrard claims that the lesser evil theory is a middle way between two greater evils. One of these greater evils arises from adopting a purely consequentialist view of defense against terrorism, in which any action which protects democratic society should be adopted, no matter which rights it violates, since preserving democracies will ultimately best protect rights. The other greater evil which she discerns results from what she calls perfectionism is the view that rights must act as absolute constraints on action, so that we are never justified in violating them (Garrard, 2005, p. 30). The lesser evil theory is a dynamic theory given the contexts of various situations and it is not a measure of last resort. Its focus on the consequences is undeniable. Its situational approach is a great benefit as it can choose whether to consider the lesser evils and avoid the greater ones. It does not totally exclude the possibility of inhumane practices or of limiting people's liberties to minimize evil and negative consequences. Such behavior may be right and justified by the consequences. Focusing on lesser evils may eventually be considered a necessary moral failure-preventing moral disasters from happening.

One more question has to be answered: Who will guarantee that resorting to a lesser evil will remain a checked and limited, justified means of securing safety? The answer is liberal democracy, as it has the many control mechanisms to do so. It has lasted for decades because it has institutions to deal with morally hazardous reactions to the actions and behaviors of the moral subjects living within or outside it. The use of political means seems necessary to successfully control the use of lesser evils. This has to be supervised and agreed on by the majority of people and institutions involved. If we fail to do that, the lesser evil will remain unchecked and it is very likely that the temporary removal of some civilian liberties might end in people's basic human rights and liberties being constantly violated, in civilians having to live in fear and in many other negative consequences that are very often identified as aspects of terrorism. Despite these real hazards and the dangers of committing an evil act, it is highly probable that using the lesser evil theory and the doctrine of double effect may be an effective way of preventing man-made moral disasters.

\section{Conclusion}

The Charlie Hebdo attacks cannot, by any means, be justified by the idea of causing lesser evil; though, I am quite fond of the idea that they could have been avoided had the theory been used. Avoiding them would have resulted in the saving of innocent lives (innocent in the sense that they had not caused physical harm to anyone). Following these terrorist attacks a debate has emerged on terrorism, Islam, the Islamization of Europe and the relationship between freedom of speech and tolerance (Fassin, 2015; Rowson, 2015). One side expressly defends the idea of freedom of speech, including the publishing of cartoons mocking politicians, artists, well-known personalities, political parties, ideological movements, religious gods, etc. (Ali, 2015; McNair, 2015). On the other side, many voices draw attention to the idea that even freedom of speech has to have certain limits in the name of tolerance and the peaceful coexistence of peoples of different nationalities and ideological and religious 
beliefs (Juss, 2015; Stortz, 2015). The aim of this article was not to decide who is right and who is wrong, but to analyse the attacks from the point of view of two theoretical approaches, namely Thomas Aquinas' doctrine of double effect and Michael Ignatieff's lesser evil theory.

Since the attacks, there have been attempts to sympathize with the victims and therefore condemn the acts of terrorism as immoral, unjustifiable and intolerant. The slogan used was (and still is) "Je suis Charlie"-meaning 'I am Charlie (Hebdo)' and "I strongly condemn any violent actions against innocent civilian targets and furthermore am expressing a claim about the unlimited freedom of speech and that it should never be limited in a democratic society" (at least not to the level of mocking caricatures and illustrations). Despite the large number of people declaring that they are Charlie, I am not sure they all realize the proposition hidden in that declaration. As I have stated, spreading certain ideas may be a security risk for a community/society and its citizens. I believe that irony, satire and caricatures are an important part of art and culture in any society. I suggest it should be created in line with political correctness and that there are certain boundaries and limits that should never be crossed, since once that has occurred, it becomes pointless, vulgar, rough, provocative and an attempt to attack public or historical figures, religious representatives or the whole systems of cultural and religious values and beliefs.

The aim of this paper was not to evoke any feelings of hatred or contempt for the victims of the Charlie Hebdo attacks, but to find an objectively impartial standpoint that would reject true terrorism as obviously evil. The use of satire, irony and mockery for such purposes is a headless attempt to justify all the freedoms. On the other hand, this article does not suggest we should praise or glorify the victims of these attacks and nor does it see them as symbols of heroism, courage and the unbreakable power of freedom of speech. The actions of the caricaturists were intolerable and such intolerance is unacceptable. If they are presented to the public, it is our moral duty to reject and disapprove such cynicism and intolerance and secure the safety of the community by all means necessary. If there is just cause to take necessary measures, that does not mean more harm and evil should be caused. If we have a justified reason for limiting civilian liberties, we must ensure that it is done circumspectly and that the potential negative consequences of our actions may never outweigh the negative consequences that might occur if we choose not to act. In this context it is important that we do not compare the situation before our action with the situation after our action as these are diametrically incomparable. It is wiser to compare the future situation that will arise if we choose not to act with the situation that may occur if we do act. Condemning intolerant and abusive activities by the members of a particular society (or any other society) is a moral imperative and an inevitable stimulus for eliminating evil as such. We must not forget the limits of our own liberties end where the liberties of others start. When actions and behaviours violate the basic moral values and principles of human coexistence, it is of great importance that they are condemned and judged as being immoral and wrong.

\section{Acknowledgement}

Funding for the workshop on moral theories and disasters at the University of Prešov, Slovakia (13-15 May 2015) and open-access publication was provided by COST Action IS1201 (http://DisasterBioethics.eu). 


\section{References}

Ali, A. H. (2015). How to respond to Islamist Kalashnikovs in the Heart of Paris. New Perspectives Quarterly, 35(2), 45-47.

Aquinas, T. (1938). Theologická summa. [Summa theologica]. Olomouc: Bohovědné učiliště řádu Dominikánského.

Connell, F.J. (1967). Principle of double effect. In New Catholic encyclopedia (Vol. 4, pp. 1020-1022). New York: McGraw-Hill.

Cole, J. (2013). Human sacrifice in Walzer's just war theory. Retrieved from http://www.westmont.edu/ institute/conversations/2013_program/documents/cole.pdf

Dworkin, R. (2002). The threat to patriotism. In C. Calhoun et al. (Eds.), Understanding September 11 (pp. 273-285). New York: New Press.

Fassin, D. (2015). In the name of the Republic: Untimely meditations on the aftermath of the Charlie Hebdo attack. Anthropology Today, 31(2), 3-7.

Garrard, E. (2005). The lesser evil: Political ethics in an age of terror. Democratiya 1(2). Retrieved from http://www.dissentmagazine.org/democratiya_article/the-lesser-evil-political-ethics-in-anage-of-terror

Graham, G. (2008). Ethics and international relations. Oxford: Blackwell Publishing.

Hoffman, B. (2006). Inside terrorism. New York: Columbia University Press.

Ignatieff, M. (2005). The lesser evil: Political ethics in an age of terror. Toronto: Penguin Canada.

Juss, S. (2015). Burqa-bashing and the Charlie Hebdo cartoons. King's Law Journal, 26(1), 27-43.

McIntyre, A. (2014). Doctrine of double effect. In Stanford encyclopedia of philosophy. Retrieved from http://plato.stanford.edu/entries/double-effect/

McNair, B. (2015). The Interview: Schnarking, Knob Jokes and the right to cause gross offence. Journalism Practice, 9(3), 452-454.

Mill, J.S. (1978). On liberty. Cambridge: Hackett publishing.

Rawls (1999). The law of peoples with "The idea of public reason revisited“. Cambridge, MA: Harvard University Press.

Rowson, M. (2015). Pushing laughter to its very limits. British Journalism Review, 26(1), 19-26.

Stortz, M. E. (2015). What's in a name? Dialog: A Journal of Theology, 54(2), 111-112.

Švaňa, L. (2013). Etika a nábožensky motivovaný terorizmus. [Ethics and religiously motivated terrorism]. In M.Ološtiak \& M. Chovanec (Eds.), 8. Študentská konferencia: zborník plných príspevkov. [8 $8^{\text {th }}$ Student Conference: Book of Proceedings] (pp. 224-230). Prešov: Prešovská univerzita v Prešove.

Ústava SR (1992). [Constitution of the Slovak Republic]. Retrieved from www.slpk.sk/dokumenty/ ustava.pdf

Walzer, M. (1977). Just and unjust wars. New York: Basic Books.

Walzer, M. (2004). Arguing about war. New Haven: Yale University Press.

Institute of Ethics and Bioethics,

Faculty of Arts,

University of Prešov,

17 Novembra 1 ,

SK-08078 Prešov,

Slovakia

E-mail: lukas.svana@yahoo.com 